\title{
Perforace cípu aortální chlopně při infekční endokarditidě
}

\author{
Jan Dominik, Martin Tuna, Pavel Žáček \\ Kardiochirurgická klinika, Fakultní nemocnice Hradec Králové a Univerzita Karlova v Praze, Lékařská fakulta v Hradci Králové, Hradec \\ Králové, Česká republika
}

Úvod: Infekční endokarditida, i přes všechny pokroky moderní medicíny, zůstává stále zákeřnou a život ohrožující chorobou. Přichází nečekaně, průběh je nevyzpytatelný, mnohdy velmi dramatický, a často jedinou nadějí pro nemocného je chirurgické řešení.

Popis případu: U 40letého, do té doby zdravého muže, se po týdnu trvajícím kašli s teplotami rozvinula pneumokoková sepse se sekundární purulentní meningitidou. Nemocný byl přijat na kliniku infekčních chorob. V hemokulturách byl prokázán Streptococcus pneumoniae, v moči pneumokokový antigen a přítomna byla i masivní pozitivita na pneumokoka v likvoru metodou PCR. Po definitivním průkazu etiologického agens byl původně nasazený ceftriaxon nahrazen penicilinem G. Ve třetím týdnu hospitalizace se objevil šelest na srdci a při ultrazvukovém vyšetření byla popsána aortální regurgitace a suspektní vegetace na aortální chlopni. Nemocný byl proto odeslán

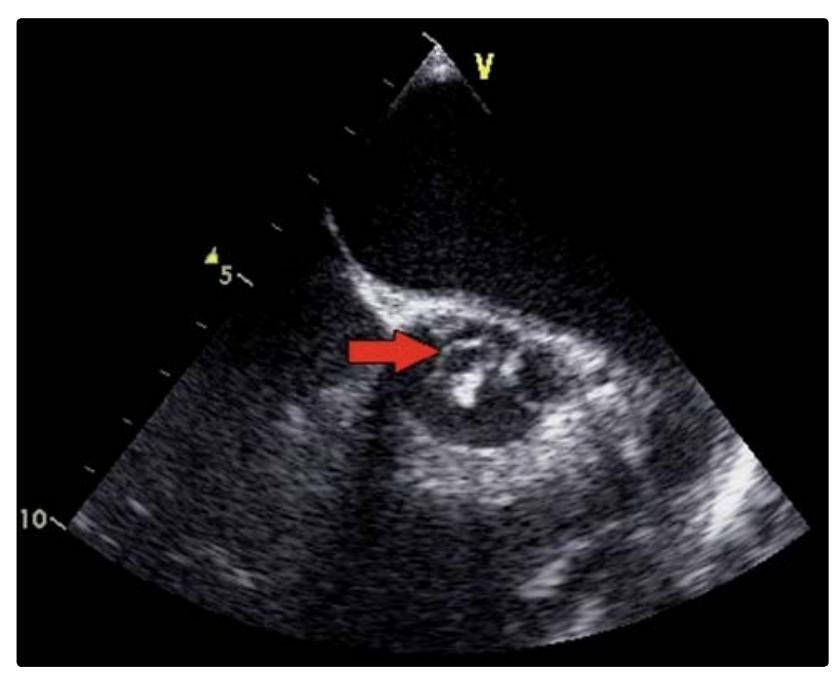

Obrázek 1 Transesofageální echokardiografie, příčná projekce aortální chlopně s nálezem perforace nekoronárního cípu na naši kliniku k rozhodnutí o dalším postupu a $\mathrm{k}$ provedení transesofageální echokardiografie (TEE). Při ní byla prokázána destrukce prolabujícího nekoronárního cípu aortální chlopně s vegetací $5 \times 2 \mathrm{~mm}$ na jeho okraji. V cípu byl defekt o průměru $6 \mathrm{~mm}$ (obrázky 1,2). Významná aortální regurgitace byla asi $10 \mathrm{~mm}$ širokým proudem jednak perforací, ale i okolo prolabujícího cípu excentricky až do hrotu levé komory (obrázek 3) s holodiastolickým obrácením toku $\mathrm{v}$ descendentní aortě. $\mathrm{V}$ léčbě byl $\mathrm{k}$ penicilinu přidán gentamicin a po šesti dnech byla provedena operace. Nález na chlopni odpovídal popisu TEE. Nekoronární cíp byl rozbředlý, byl v něm rozsáhlý defekt a na jeho okraji při anulu byla vegetace (obrázek 4). Aortální chlopeň byla excidována, anulus dezinfikován a implantována dvoulistá mechanická chlopeň St. Jude Medical Regent 19. Pooperační průběh byl bez komplikací, pokračovalo se v intravenózní antibiotické léčbě. Dvanáctý pooperační den

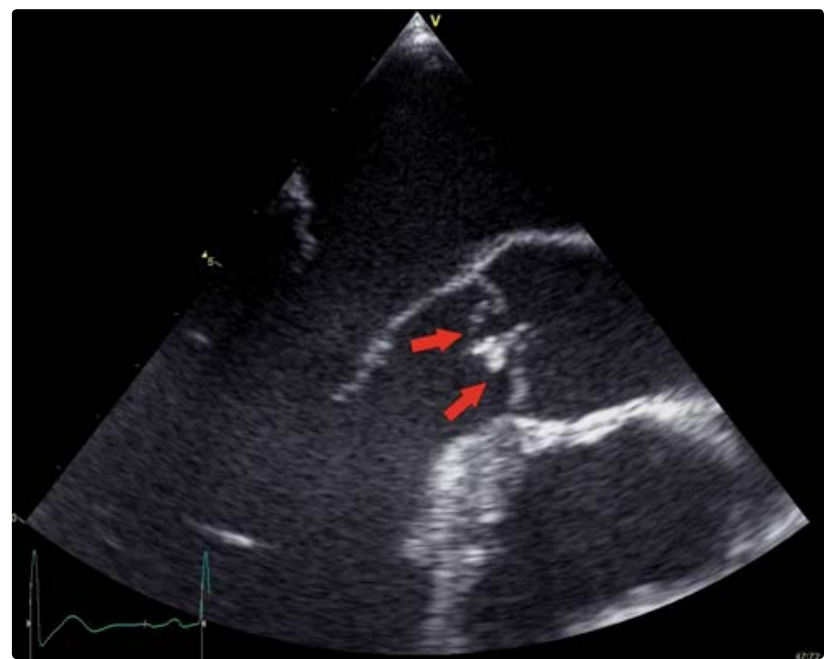

Obrázek 2 Transesofageální echokardiografie, podélná projekce aortální chlopně s prolapsem, perforací a vegetací nekoronárního cípu

Adresa: prof. MUDr. Jan Dominik, CSc., Kardiochirurgická klinika, FN Hradec Králové a LF UK, Sokolská 581, 50005 Hradec Králové, Česká republika, e-mail: dominik@fnhk.cz 


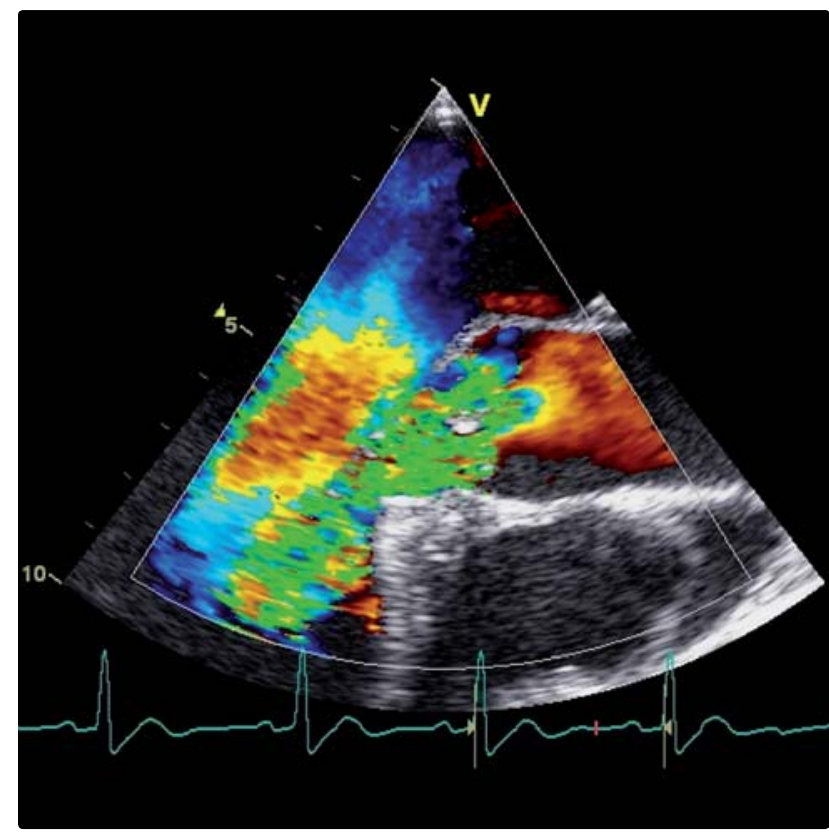

Obrázek 3 Transesofageální echokardiografie, barevné dopplerovské mapování se zobrazením masivní aortální regurgitace

byl nemocný propuštěn domů $s$ doporučením, aby ještě dalších 14 dnů užíval amoxicilin a nechal se očkovat proti pneumokoku. Při kontrole za tři měsíce po operaci je pacient zcela bez obtíží, bez známek infekce; echokardiografické vyšetření prokazuje normální funkci mechanické chlopně bez známek paravalvární regurgitace.

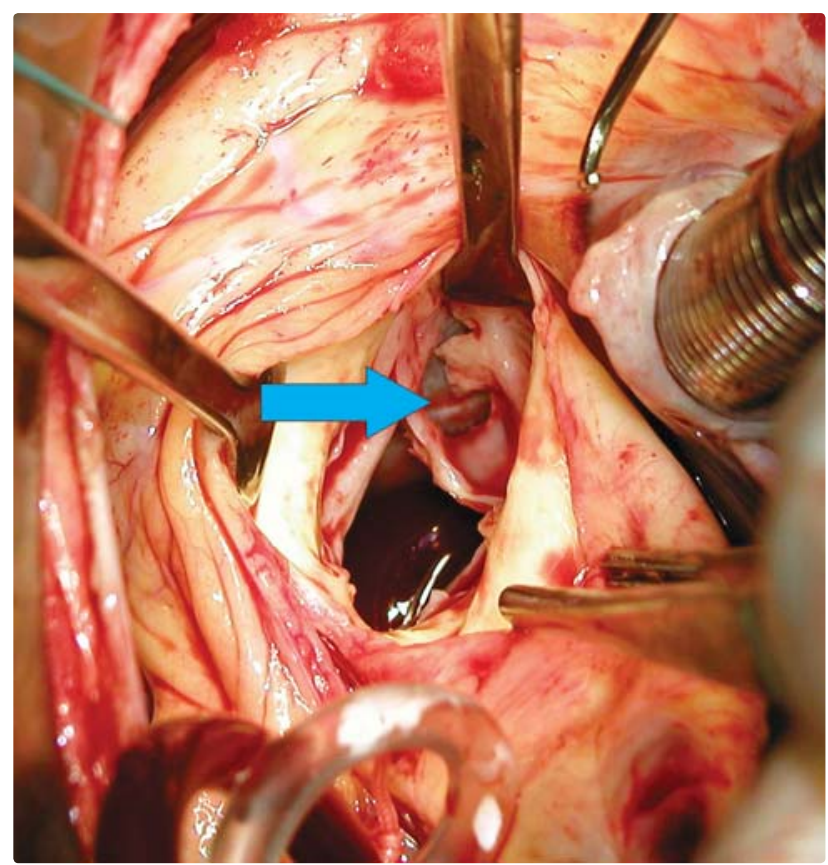

Obrázek 4 Defekt v nekoronárním cípu aortální chlopně s vegetací

\section{Základní literatura}

1. Beneš J. Infekční endokarditida. V: Aschermann M. Kardiologie. Praha: Galén 2004:860-72.

2. Hricák V. Infekčná endokarditída. Bratislava: SAP, 2001:152.

3. Beneš J, Gregor P, Mokráček A. Doporučení pro diagnostiku, léčbu a profylaxi infekční endokarditidy. Cor Vasa 2007;49 (6 Suppl K):157-71. 